\title{
THE TRUTH IS JESUS CHRIST IN THE GOSPEL OF JOHN ON THE APPROACH OF POPPER'S FALSIFICATION
}

\author{
Khoe Yao Tung \\ Education Faculty, Pelita Harapan University Jakarta \\ E-mail: Khoe.tung@lecturer.uph.edu
}

\begin{abstract}
Many attempts to defend the concept of a Christian understanding of the Truth $(\dot{\alpha} \lambda \dot{\eta} \theta \varepsilon i \alpha)$ especially in the Gospel of John. To defend the Christianity concept of truth, believe The Truth is Jesus Christ himself. Secular scholars attempt to ruin this concept with many theories and principles. They have been continuing to reject this epistemology based on the philosophy of science and questioning what is the Truth and what is the connection with Jesus Christ. To defend this concept, an approach of Karl Popper's falsification theory is used to justify the truth is Jesus Christ Himself in the Gospel and letters of John.
\end{abstract}

Keywords: $\dot{\alpha} \lambda \dot{\eta} \theta \varepsilon \imath \alpha$, truth, Popper falsification, Gospel of John, Gospel and letters of John, philosophy of science.

\section{INTRODUCTION}

In Christian doctrine, the Truth is God, and the Truth is Jesus Christ himself (John 14:6). The truth about who is Jesus Christ, the Truth about God's Word and the Word became flesh and dwelt among us (John 1:14). The secular community always asked many questions about Jesus and the Truth, who is Jesus, what is the Truth, what is the relationship between the Truth and Jesus Christ. This research uses Popper's Falsification theory one of the branches of the "secular" philosophy of science, to make the justification of the hypothesis about the Truth in the Gospel of John. The consistency of the Gospel of John about the truth to lead the truth is Jesus Himself.

From a secular perspective, they questioned what was the truth, what the meaning of the truth is Jesus Himself until Jesus Christ declares himself was a God. Yet if we could test in Philosophy of Science, that the truth is Jesus itself then the implication taken many implications in Christianity and also for the secular community.

From in Christian Perspective, the way of truth is taken when Jesus gives her life for sinners in need of forgiveness, atonement, and 
justification (Mackinnon, 2009, 22). He shows us that, even though we are forgiven, we still have sin in the flesh, and are powerless to overcome when we are tempted to give in to the sin that is so rooted in us as human beings. Only we believe dan dependent on God's truth, we can conquest over the lusts of the flesh which lead to sin. "And we know that the Son of God has come and has given us an understanding, that we may know Him who is true; and we are in Him who is true, in His Son Jesus Christ. This is the true God and eternal life" (1 John 5:20).

\section{METHODOLOGY}

Methodology in this paper uses Popper's Falsification theory to justify whether the Truth is about Jesus Christ Himself. The first step in this research paper is finding all the words of truth and their meaning about the truth in the Gospel and letters of John including the Gospel of John, 1 John, 2 John, and 3 John. After data is collected then the coding is needed to be referred to as the interpretation of the meaning of the data or could be understood as the in-depth analysis of data Miles et al. (2014). Codes were gathered through the reoccurring patterns of data chunks based on similar categories or known as pattern codes.
In the second step, the interconnected categories were grouped to provide a more significant level of meaning. Lastly, is to give them in terms of validation and justification, the idea of the truth and make it corresponding whether matching or unmatching as a validation to the hypothesis. The final step is to make a Popper's justification whether all verses truth in Gospel and letters of John supporting the hypothesis or there is one verse or more that contradicts the hypothesis

\section{Popper justification}

In the philosophy of science, a standard of evaluation of putatively scientific theories, according to which a theory is genuinely scientific only if it is possible in principle to establish that it is false. Popper's Falsification theory is the branch of philosophy of science to justify whether the hypothesis is accepted or rejected.

Karl Popper (1902-1994) proposed the criterion of falsifiability for validating the theory of empirical judgments by observing inconsistent empirical predictions. So that the scientific theories are instead incrementally validated through the absence of disconfirming evidence in several well-designed experiments. According to Popper, some disciplines that 
have claimed scientific validity are not empirical sciences, because their subject matter cannot be falsified in this manner.

For Popper, an accepted theory should attempt to invalidate a theory, rather than attempt to continually support theoretical hypotheses. In this philosophy of science when there is a hypothesis that "all swans are white," can be falsified by observing a black swan; if in this situation there is a black swan then a hypothesis of "all swans are white" is rejected (Popper, 2002, p 361). Popper states that for a proposition to be considered accepted theory then it must be able to be tested and conceivably proven false. With the same condition, a hypothesis in this paper is "The truth is Jesus Christ" can be falsified by observing The Truth is not refer to Jesus Christ. Then the hypothesis the truth is Jesus Christ himself is refuted.

\section{Observation}

In this research, the first step is to acquire all about the word of truth $(\dot{\alpha} \lambda \dot{\eta} \theta \varepsilon 1 \alpha)$ in the Gospel of John. Afterward, categorization in needed to prepare and organize all of the data acquiring for further analysis. Miles et al. (2014) referred to coding as the interpretation of the meaning of the data or could be understood as the in-depth analysis of data. Codes were gathered through the reoccurring patterns of data chunks based similar categories or known as pattern codes.

The second step, the interconnected categories were grouped together to provide a more significant level of meanings. Lastly, is to give them in terms of validation and justification, the idea of the truth and make it corresponding whether matching or unmatching as a validation to the hypothesis. The final step is to make a Popper's justification whether all verses truth in Gospel of John supporting the hypothesis or there is one verse or more that contradicts the hypothesis. 


\section{The Truth ( $\dot{\alpha} \lambda \dot{\eta} \theta \varepsilon ı \alpha)$ verses in the Gospel of John}

No Verses in the Gospel of John

1. John 1:14 NIV

14 The Word became flesh and made his dwelling among us. We have seen his glory, the glory of the one and only Son, who came from the Father, full of grace and truth.

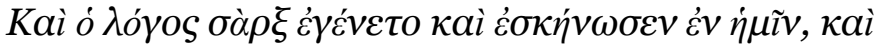

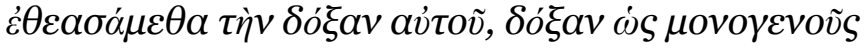

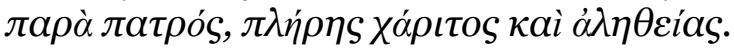

2. John 1:17 NIV

17 For the law was given through Moses; grace and truth came through Jesus Christ.

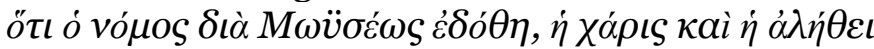

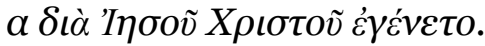

3. John 3:21 NIV

21 But whoever lives by the truth comes into the light, so that it may be seen plainly that what they have done has been done in the sight of God.

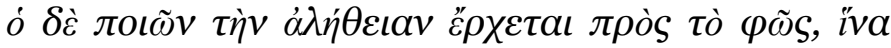

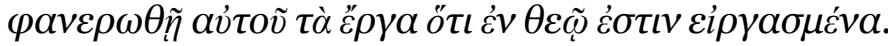

4. John 4:23 NIV

23 Yet a time is coming and has now come when the true worshipers will worship the Father in the Spirit and in truth, for they are the kind of worshipers the Father seeks.

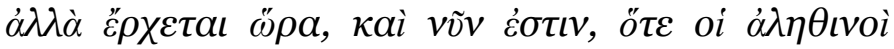

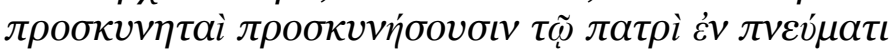

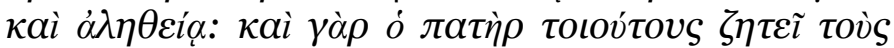

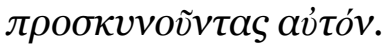

5. John 4:24 NIV

24 God is spirit, and his worshipers must worship in the Spirit and in truth."

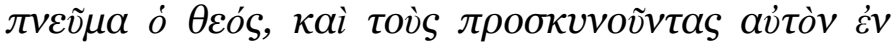

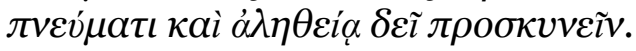

6. John 5:33 NIV

33 "You have sent to John and he has testified to the truth.

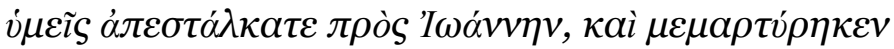
$\tau \tilde{\eta} \dot{\alpha} \lambda \eta \theta \varepsilon \dot{\alpha} \alpha:$

7. John 7:18 NIV

18 Whoever speaks on their own does so to gain personal glory, but he who seeks the glory of the one
Interpretation categories

Came from Father (God), that God full of grace and truth.

Grace and truth came through Jesus Christ.

The characteristic expression for 'grace and truth' is eleos

['mercy'] kai alētheia; in (compare Jn. 1:14 charis kai alētheia).

Truth comes into the light

The true worshipers will worship the Father in the Spirit and in truth

Worship in the Spirit and in truth

He has testified to the truth.

A man of truth; there is nothing false about him. 
who sent him is a man of truth; there is nothing false about him.

$\dot{o} \alpha \varphi^{\prime} \dot{\varepsilon} \alpha v \tau o \tilde{v} \lambda \alpha \lambda \tilde{\omega} v \tau \grave{\eta} v \delta o ́ \xi \alpha v \tau \grave{\eta} v i \delta i \alpha v \zeta \eta \tau \varepsilon \tilde{\imath}: \dot{o} \delta \dot{\varepsilon} \zeta \eta$

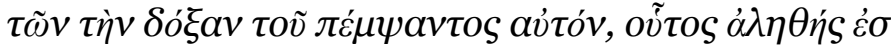

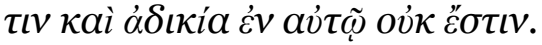

8. John 8:32 NIV

32 Then you will know the truth, and the truth will set you free."

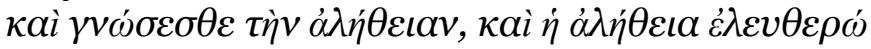

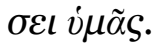

9. John 8:40 NIV

40 As it is, you are looking for a way to kill me, a man who has told you the truth that I heard from God. Abraham did not do such things.

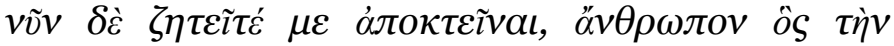

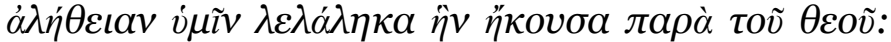

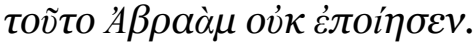

10. John 8:44 NIV

44 You belong to your father, the devil, and you want to carry out your father's desires. He was a murderer from the beginning, not holding to the truth, for there is no truth in him. When he lies, he speaks his native language, for he is a liar and the father of lies.

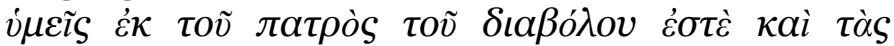

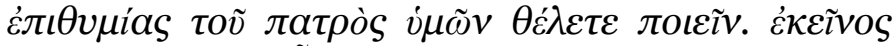
$\dot{\alpha} v \theta \rho \omega \pi$

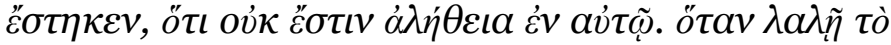

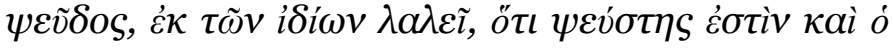

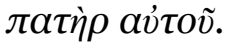

11. John 8:45 NIV

45 Yet because I tell the truth, you do not believe me!

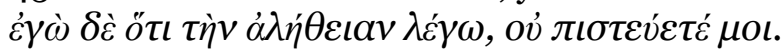

John 8:46 NIV

46 Can any of you prove me guilty of sin? If I am telling the truth, why don't you believe me?

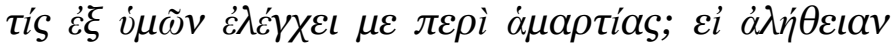

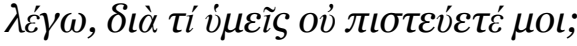

12. John 14:6 NIV

6 Jesus answered, "I am the way and the truth and the life. No one comes to the Father except through me.

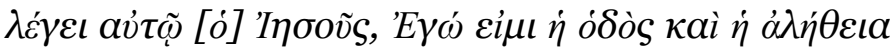

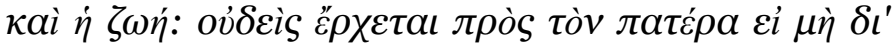
$\dot{\varepsilon} \mu o \tilde{v}$.

13. John 14:17 NIV
The truth will set you free.

Abraham's descendants are not from God

There is no truth in the devil.

Jesus tell the truth

Jesus tell the truth

Jesus is the truth 
17 the Spirit of truth. The world cannot accept him, because it neither sees him nor knows him. But you know him, for he lives with you and will be in you.

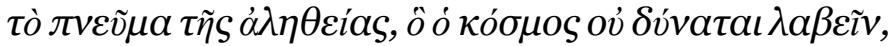

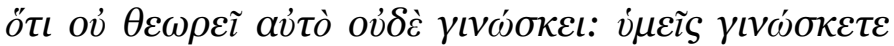

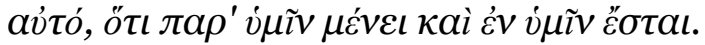

14. John 15:26 NIV

26 "When the Advocate comes, whom I will send to you from the Father-the Spirit of truth who goes out from the Father-he will testify about me.

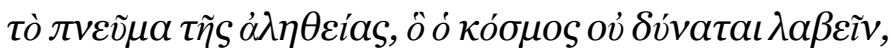

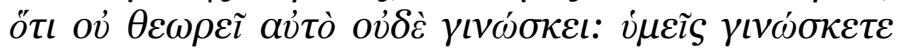

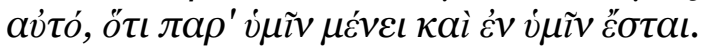

15. John 16:13 NIV

13 But when he, the Spirit of truth, comes, he will guide you into all the truth. He will not speak on his own; he will speak only what he hears, and he will tell you what is yet to come.

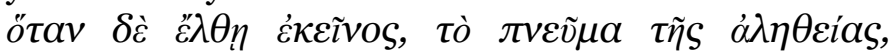

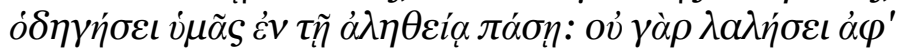

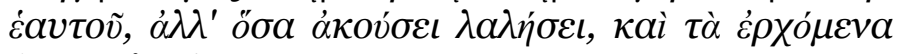
$\dot{\alpha} v \alpha \gamma \gamma \varepsilon \lambda \varepsilon \tilde{\varepsilon} \dot{v} \mu \tilde{i} v$.

16. John 17:17 NIV

17 Sanctify them by the truth; your word is truth.

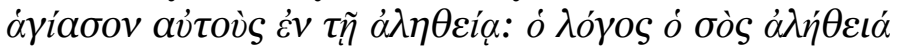
Éotıv.

17. John 18:23 NIV

23 "If I said something wrong," Jesus replied, "testify as to what is wrong. But if I spoke the truth, why did you strike me?"

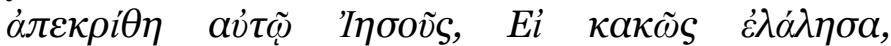

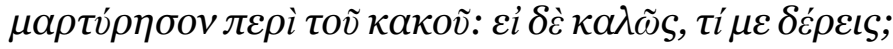

18. John 18:37 NIV

37 "You are a king, then!" said Pilate. Jesus answered, "You say that I am a king. In fact, the reason I was born and came into the world is to testify to the truth. Everyone on the side of truth listens to me."

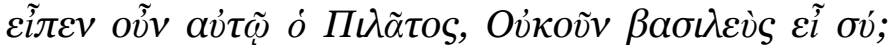

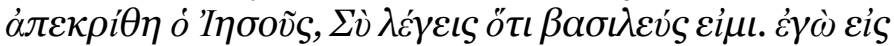

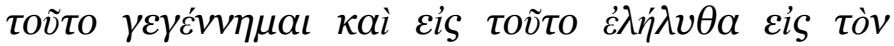
$\kappa o ́ \sigma \mu o v, i ́ v \alpha \mu \alpha \rho \tau v \rho \dot{\eta} \sigma \omega \tau \tilde{\eta} \dot{\alpha} \lambda \eta \theta \varepsilon i \dot{\alpha}: \pi \tilde{\alpha} \varsigma \dot{o} \hat{\omega} v \dot{\varepsilon} \kappa \tau \tilde{\eta} S$ $\dot{\alpha} \lambda \eta \theta \varepsilon i \alpha \varsigma \alpha \dot{\alpha} \kappa o v ́ \varepsilon \iota ~ \mu o v ~ \tau \tilde{\eta} \varsigma \varphi \omega v \tilde{\eta} \varsigma$.

19. John 18:38 NIV
We know the spirit of truth, for he lives with you and will be in you.

The Spirit of truth who goes out from the Father-he will testify about Jesus.

The Spirit of truth will guide you into all the truth.

The word is truth, and The Word became flesh and made his dwelling among us (cf. John 1:14)

Jesus spoke the truth.

Everyone on the side of truth listens to Jesus. 
38 "What is truth?" retorted Pilate. With this he went out again to the Jews gathered there and said, "I find no basis for a charge against him.

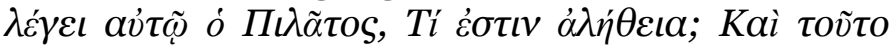

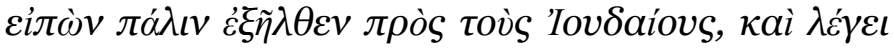

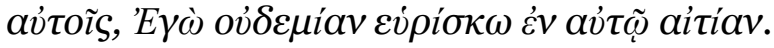

\section{John 19:35 NIV}

35 The man who saw it has given testimony, and his testimony is true. He knows that he tells the truth, and he testifies so that you also may believe.

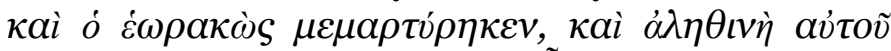

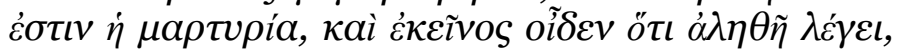

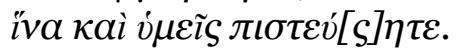

21. 1 John 1:6 NIV

6 If we claim to have fellowship with him and yet walk in the darkness, we lie and do not live out the truth.

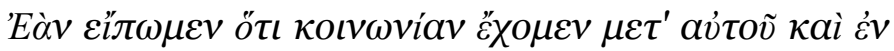

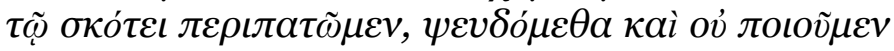
$\tau \dot{\eta} v \dot{\alpha} \lambda \dot{\eta} \theta \varepsilon \iota \alpha v$ :

22. 1 John 1:8 NIV

8 If we claim to be without sin, we deceive ourselves and the truth is not in us.

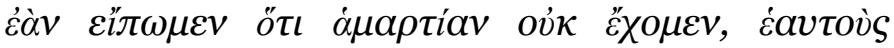

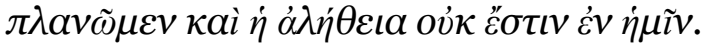

23. 1 John 2:4 NIV

4 Whoever says, "I know him," but does not do what he commands is a liar, and the truth is not in that person.

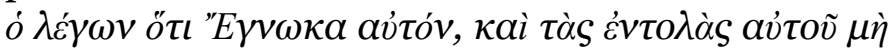

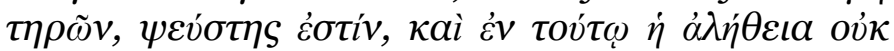

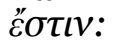

24. 1 John 2:8 NIV

8 Yet I am writing you a new command; its truth is seen in him and in you, because the darkness is passing and the true light is already shining.

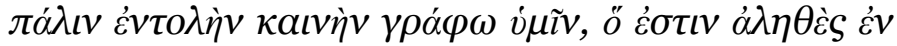

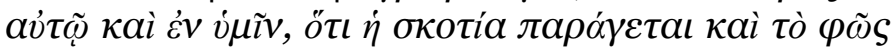

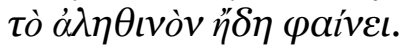

25. 1 John 2:21 NIV

21 I do not write to you because you do not know the truth, but because you do know it and because no lie comes from the truth.

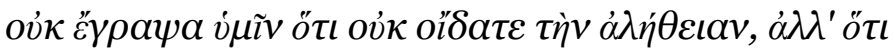

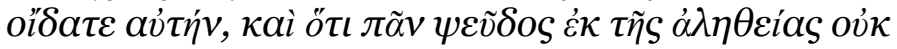
हैotıv.

26. 1 John 3:18 NIV
Pilate finds no basis for a charge against him.

He knows that he tells the truth, and he testifies so that you also may believe.

Fellowship with him will lead to the truth

the truth only in Jesus, man is always with sin.

Knowing about Jesus will lead to the truth

The true light is already shining.

No lie comes from the truth. 
18 Dear children, let us not love with words or speech but with actions and in truth.

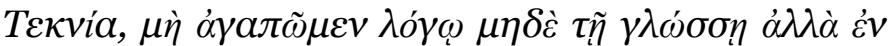

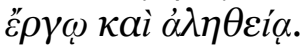

27. 1 John 3:19 NIV

19 This is how we know that we belong to the truth and how we set our hearts at rest in his presence:

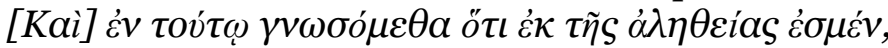

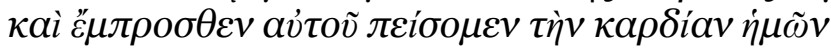

28. 1 John 4:6 NIV

6 We are from God, and whoever knows God listens to us; but whoever is not from God does not listen to us. This is how we recognize the Spirit of truth and the spirit of falsehood.

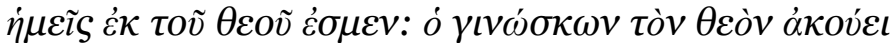

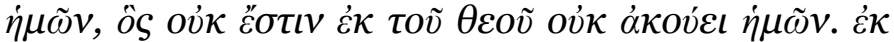

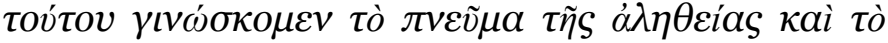
$\pi v \varepsilon \tilde{v} \mu \alpha \tau \tilde{\eta} \varsigma \pi \lambda \alpha \dot{v} \eta \varsigma$.

29. 1 John 5:6 NIV

6 This is the one who came by water and bloodJesus Christ. He did not come by water only, but by water and blood. And it is the Spirit who testifies, because the Spirit is the truth.

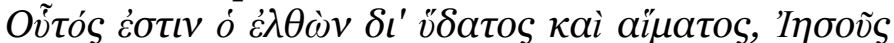
X

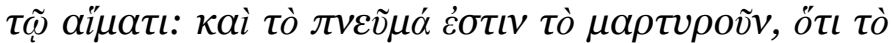

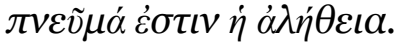

30. 2 John 1:1 NIV

1 The elder, To the lady chosen by God and to her children, whom I love in the truth-and not I only, but also all who know the truth.

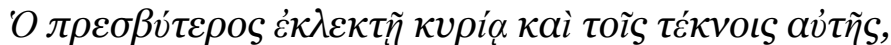

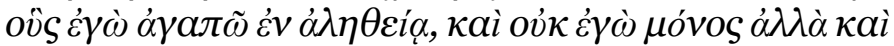

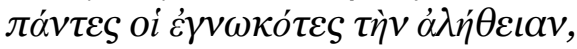

31. 2 John 1:2 NIV

2 because of the truth, which lives in us and will be with us forever:

$\delta \iota \grave{\alpha} \tau \dot{\eta} v \dot{\alpha} \lambda \dot{\eta} \theta \varepsilon \iota \alpha v \tau \grave{\eta} v \mu \varepsilon \operatorname{cov} \sigma \alpha v \dot{\varepsilon} v \dot{\eta} \mu \tilde{\imath} v, \kappa \alpha i ̀ \mu \varepsilon \theta^{\prime} \dot{\eta} \mu \tilde{\omega} v$

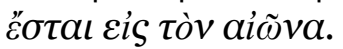

32. 2 John 1:3 NIV

3 Grace, mercy and peace from God the Father and from Jesus Christ, the Father's Son, will be with us in truth and love.
Love with actions and in truth.

We belong to the truth

We are from God and recognize the Spirit of truth and the spirit of falsehood.

the Spirit who testifies, because the Spirit is the truth.

I love in the truth-and not I only, but also all who know the truth.

Because of the truth, which lives in us and will be with us forever:

Grace, mercy, and peace from God the Father and Jesus Christ, the Father's Son, will be with us in truth and love. 


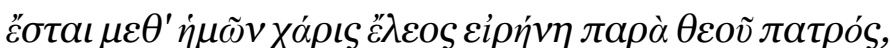

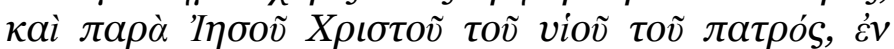

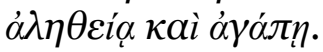

33. 2 John 1:4 NIV

4 It has given me great joy to find some of your children walking in the truth, just as the Father commanded us.

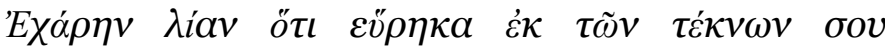

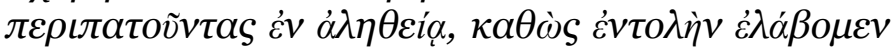

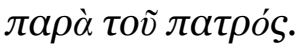

34. 3 John 1:1 NIV

1 The elder, To my dear friend Gaius, whom I love in the truth.

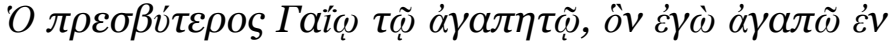
$\dot{\alpha} \lambda \eta \theta \varepsilon i \alpha$.

35. 3 John 1:3 NIV

3 It gave me great joy when some believers came and testified about your faithfulness to the truth, telling how you continue to walk in it.

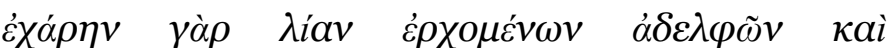

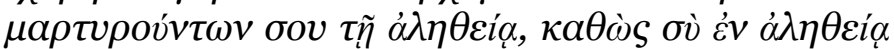
$\pi \varepsilon \rho \iota \pi \alpha \tau \varepsilon \tilde{\iota} \varsigma$.

36. 3 John 1:4 NIV

4 I have no greater joy than to hear that my children are walking in the truth.

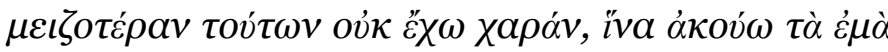

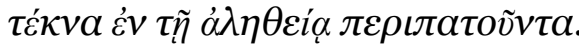

37. 3 John 1:8 NIV

8 We ought therefore to show hospitality to such people so that we may work together for the truth.

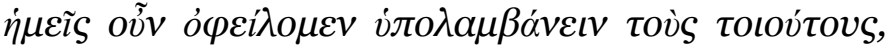

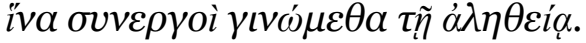

38. 3 John 1:12 NIV

12 Demetrius is well spoken of by everyone-and even by the truth itself. We also speak well of him, and you know that our testimony is true.

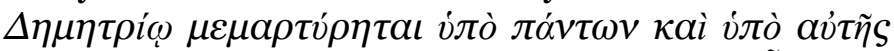

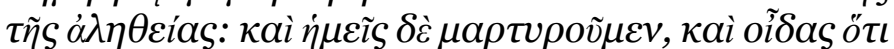

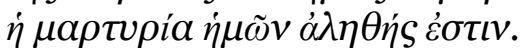

Great joy to find some of your children walking in the truth

I love the truth.

testified about your faithfulness to the truth, telling how you continue to walk in it.

I have no greater joy than to hear that my children are walking in the truth.

so that we may work together for the truth.

you know that our testimony is true. 


\section{Interconnection categories}

Interconnected categories were grouped to provide a more significant level of meaning.

The next step is that show from the view the meaning of the Truth, make it falsification with Popper's Falsification, and justification from these comparisons. These will cause us to accept or repent the hypothesis of whether the Truth is Jesus himself.

\begin{tabular}{|c|c|c|c|}
\hline No. & Categories & Verses & Validation dan Justification \\
\hline 1. & $\begin{array}{l}\text { "full of grace and } \\
\text { truth" and "grace and } \\
\text { truth" }\end{array}$ & $\begin{array}{l}\text { Jn. 1:14 } \\
\text { Jn. 1:17 }\end{array}$ & $\begin{array}{l}\text { These two verses lead the truth through } \\
\text { Jesus Christ } \\
\text { Jn. 1:14 The Word became flesh and made } \\
\text { his dwelling among us. We have seen his } \\
\text { glory, the glory of the one and only Son, } \\
\text { who came from the Father, full of grace } \\
\text { and truth. } \\
\text { Jn. } 1: 17 \text {...grace and truth came through } \\
\text { Jesus Christ. } \\
\text { - The relating verses in this categories } \\
\text { verses are matching and corresponding } \\
\text { with Popper's Falsification approach. }\end{array}$ \\
\hline 2. & $\begin{array}{l}\text { Worship in the Spirit } \\
\text { and in truth }\end{array}$ & $\begin{array}{l}\text { Jn. 4:23 } \\
\text { Jn. 4:24 }\end{array}$ & $\begin{array}{l}\text { These two verses state that worship in } \\
\text { spirit and in truth and according Jn. 1:17. } \\
\text { It lead the worship in Spirit and through } \\
\text { Jesus Christ. } \\
\text { Jn. 4:23 ...the true worshipers will } \\
\text { worship the Father in the Spirit and in } \\
\text { truth, for they are the kind of worshipers } \\
\text { the Father seeks. } \\
\text { - The relating verses in this categories } \\
\text { verses are matching and } \\
\text { corresponding with Popper's } \\
\text { Falsification approach. }\end{array}$ \\
\hline 3. & $\begin{array}{l}\text { A man of truth, } \\
\text { testifified of truth, } \\
\text { will set you free. }\end{array}$ & $\begin{array}{l}\text { Jn } 5: 33 \\
7: 18: 8: 32 \\
8: 40 ; 8: 44\end{array}$ & $\begin{array}{l}\text { These several verses state that truth is } \\
\text { nothing false, testified of truth, will set you } \\
\text { free from sin. Jesus will set you free. } \\
\text { Jn. 7:18 A man of truth; there is nothing } \\
\text { false about him. } \\
\text { Jn. 8:32 ...and the truth will set you free." } \\
\text { - The relating verses in this categories } \\
\text { verses are matching and } \\
\text { corresponding with Popper's } \\
\text { Falsification approach. }\end{array}$ \\
\hline 4. & Jesus tells the truth & $\begin{array}{l}\text { Jn } 8: 45,46 \\
\text { Jn 14:6 } \\
\text { 1Jn. 1:8 } \\
\text { Jn. 17:17 } \\
\text { Jn. 18:37 } \\
\text { Jn. 18:38 } \\
\text { 1Jn. 1:8 } \\
\text { 3Jn. 1:12 }\end{array}$ & $\begin{array}{l}\text { These several verses state Jesus always } \\
\text { tells the truth. } \\
\text { Jn. 14:6 I am the way and the truth and the } \\
\text { life. No one comes to the Father except } \\
\text { through me. } \\
\text { Jn 17:17 Sanctify them by the truth; your } \\
\text { word is truth. } \\
\text { - The relating verses in this categories } \\
\text { verses are matching and }\end{array}$ \\
\hline
\end{tabular}




\begin{tabular}{|c|c|c|c|}
\hline & & & $\begin{array}{l}\text { corresponding with } \quad \text { Popper's } \\
\text { Falsification approach. }\end{array}$ \\
\hline 5 . & Spirit of Truth & $\begin{array}{l}\text { Jn. 14:17 } \\
\text { Jn. 15:26 } \\
\text { Jn. 16:13 } \\
\text { 1Jn. 5:6 } \\
\text { 3 Jn. 1:8 }\end{array}$ & $\begin{array}{l}\text { These several verses will lead the Spirit of } \\
\text { Truth will refer Jesus is the Truth } \\
\text { Jn 15:26 The Spirit of truth who goes out } \\
\text { from the Father-he will testify about } \\
\text { Jesus. } \\
\text { Jn 16:13 The Spirit of truth will guide you } \\
\text { into all the truth. } \\
\text { - The relating verses in this categories } \\
\text { verses are matching and } \\
\text { corresponding with Popper's } \\
\text { Falsification approach. }\end{array}$ \\
\hline 6. & $\begin{array}{l}\text { Knowing Truth lead } \\
\text { to Jesus }\end{array}$ & $\begin{array}{l}\text { Jn. 3:21 } \\
\text { 1Jn 2:8 } \\
\text { 1Jn. 2:4 } \\
\text { 1Jn. 2:21 }\end{array}$ & $\begin{array}{l}\text { These several verses will lead the truth to } \\
\text { Jesus. } \\
\text { Jn. 3:21 ...it may be seen plainly that what } \\
\text { they have done has been done in the sight } \\
\text { of God. } \\
\text { - The relating verses in this categories } \\
\text { verses are matching and } \\
\text { corresponding with Popper's } \\
\text { Falsification approach. }\end{array}$ \\
\hline 7. & $\begin{array}{l}\text { Love with action in } \\
\text { truth, no lie }\end{array}$ & $\begin{array}{l}\text { 1Jn. 3:18 } \\
\text { 1Jn. 4:6 } \\
\text { 2Jn. 1:1 } \\
\text { 2Jn. 1:2 } \\
\text { 2Jn. 1:3 } \\
\text { 2 Jn. 1:4 }\end{array}$ & $\begin{array}{l}\text { These several verses state the relation the } \\
\text { truth with love and no lie. } \\
\text { 1Jn 3:18 ... let us not love with words or } \\
\text { speech but with actions and in truth. } \\
\text { 1Jn 4:16 We are from God, and whoever } \\
\text { knows God listens to us; but whoever is } \\
\text { not from God does not listen to us. This is } \\
\text { how we recognize the Spirit of truth and } \\
\text { the spirit of falsehood. } \\
\text { - The relating verses in this categories } \\
\text { verses are matching and } \\
\text { corresponding with Popper's } \\
\text { Falsification approach. }\end{array}$ \\
\hline 8. & Belong to the truth & $\begin{array}{l}\text { 1Jn. 3:19 } \\
\text { 3Jn. 1:1 } \\
\text { 3Jn. 1:3 } \\
\text { 3Jn. 1:4 }\end{array}$ & $\begin{array}{l}\text { These several verses will lead the truth is } \\
\text { Jesus, and telling how to walk in it. } \\
\text { 1Jn. 3:19 we know that we belong to the } \\
\text { truth and how we set our hearts at rest in } \\
\text { his presence } \\
\text { 3Jn. 1:3 It gave me great joy when some } \\
\text { believers came and testified about your } \\
\text { faithfulness to the truth, telling how you } \\
\text { continue to walk in it. } \\
\text { - The relating verses in this categories } \\
\text { verses are matching and } \\
\text { corresponding with Popper's } \\
\text { Falsification approach. }\end{array}$ \\
\hline
\end{tabular}


The letter of 1 John, has the word

\section{Observation of Justification}

The noun form of "truth" ( $\alpha \lambda \dot{\eta} \theta \varepsilon 1 \alpha)$ occurs 25 times in the Gospel of John, 9 times in 1 John, 5 times in 2 John, and 6 times in 3 John. The first introduction to the term in the Gospel of John occurs in the prologue $(1: 14,17)$. The Word which came and dwelt among us is "full of grace and truth" and "grace and truth" came through Jesus Christ. In the first two occurrences of the term, "truth" is related to Jesus Christ, the incarnate Word.

In the gospel of John, Jesus says that his words are "true" at least seven times (i.e. 8:13-14, 26, 31-32). In John 5:33, Jesus says that John the Baptist "bore witness to the truth." John the Baptist came bearing witness to the Messiah who would come after him- Jesus. In the most explicit statement in the Gospel, Jesus himself says in 14:6, "I am the way, the truth, and the life". In the Gospel of John, the "truth" is Jesus Christ. Three passages help us to understand what John 4:23-24 means because both terms "Spirit" and "truth" are used in a single phrase. In John 14:17; $15: 26 ; 16: 13$, the Paraclete is referred to as the "Spirit of truth". One passage speaks worship in Spirit and

truth in John 4:23-24. "truth" 9 times. In 1 John 2:3-6, And by this, we know that we have come to know him if we keep his commandments. Whoever says "I know him" but does not keep his commandments is a liar, and the truth is not in him, but whoever keeps his word, in him truly the love of God is perfected. By this we may know that we are in him: whoever says he abides in him ought to walk in the same way in which he walked. For John, "keeping his commandments" refers to "believing in the name of his Son Jesus" and "loving one another".

The letter of 2 John only has 13 verses and the first 4 verses have the word "truth" 5 times. The statement of $\mathrm{He}$ and all the others "who know the truth" write to the elected lady "whom I love in truth". John rejoices that some of her "children are walking in the truth, just as we were commanded by the Father" (2 John 4).

The letter of 3 John only has 15 verses and mentions "truth" 6 times. John writes to Gaius whom he "loved in truth". He says, "For I rejoiced greatly when the brothers came and testified to your truth, as indeed you are walking in the truth. I have no greater joy than to hear that my children are walking in the truth." (3 John 1:3-4) John was overjoyed they were walking in the truth. 
All verses in the Gospel and letters of John about the truth $(\dot{\alpha} \lambda \dot{\eta} \theta \varepsilon \imath \alpha)$ are consistent of the truth leads to an individual of Jesus ${ }^{1}$ lead to that the truth is Jesus himself. In the beginning, the truth from the Word became flesh and made his dwelling among us. We have seen his glory, the glory of the one and only Son, who came from the Father, full of grace and truth (John 1:14). Grace and truth came through Jesus Christ (John 1:17). Then the truth comes into the light (John 3:21), The truth will set you free (John 8:32), Jesus tells the truth (John 8:45,46) and the final statement is Jesus answered, "I am the way and the truth and the life. No one comes to the Father except through me (John 14:6).

The other supporting verses correspond with the matching with the concept of truth that leads to an individual of Jesus. According to Popper's falsification, there is no conflict among verses in the Gospel and letters of John about truth, there is no single verse that contradicts will lead the hypothesis will be rejected. So, the observation of justification of Popper's falsification satisfies the statement the Truth is Jesus Christ.

\footnotetext{
${ }^{1}$ Bauckham (2015, pp 6-7) in the Gospel of glory shows us that there are sixty-seven aphoristic sayings about the individual's relationship with Jesus. He expressions that the Gospel of John with 5 types. There are type 1 . "The one who ..." (ho + participle) with 37 sayings, type 2. "If anyone..."
}

\section{Implications}

The implication of the truth is Jesus Himself is the truth is the life of Jesus which is to be manifested in us. (2 Corinthians 4:10). Jesus is the truth will proclaim Jesus is the Son of God and the Triune God. The use of Popper falsification is an indisputable reason for secularism that Jesus Himself is the truth. The analysis of the truth $(\dot{\alpha} \lambda \dot{\eta} \theta \varepsilon ı \alpha)$ also gives the meaning and a concept of Truth in The Gospel of John and focuses on Jesus (Ogon, 2021, p.3) . It is deeply Christocentric (John 14:6), but also contains a Triune of God.

\section{CONCLUSION}

Popper's falsification verifies the concept of the truth is concurrent for all the verses and converges to the hypothesis that Jesus is the truth himself. This means that its philosophy of science constructs the validity of the concept of truth in the Gospel of John. The implication of the truth $(\dot{\alpha} \lambda \dot{\eta} \theta \varepsilon 1 \alpha)$ is Jesus Himself is important, in connection of the declaration of Jesus is the God, the son of God. The

(ean tis ...) with 14 sayings, type 3. "Everyone who . .." (pas ho + participle) with 12 sayings, type 4 . "Whoever..." (hos an ...) with 1 saying and type 5 . "No one ..." (oudeis ...) with 3 sayings. 
Gospel of John and the three letters of Johannine epistles exhibit strong resemblances in the theology of $\dot{\alpha} \lambda \dot{\eta} \theta \varepsilon ı \alpha$ as a declaration of Jesus is the truth himself (John 14:6).

\section{REFERENCE}

[1] Bauckham Richard (2015). Gospel of Glory Major, Themes in Johannine Theology. Grand Rapids, MI: Baker Academic a division of Baker.

[2] D. M. Mackinnon, The Christian Understanding of Truth, Published online by Cambridge University Press: 02 February 2009, Scottish Journal of Theology, Volume 1, Issue 1, February 1948, pp. 19 - 29 DOI:

https://doi.org/10.1017/S003693060 0026557.

[3] Carson D. A. (1991). Pillar New Testament Commentary (PNTC), The Gospel According to John. Grand Rapids, Michigan: William B.Eerdmans Publishing Company.

[4] Groothuis Douglas (2000). Truth Decay. Downer Grove, IL: InterVarsity Press.

[5] Ogon Bastian (2020). The Concept of Truth in The Gospel of John (Thesis defense), Andrews University, Seventh-day Adventist Theological Seminary

[6] Miles, M. B., \& Huberman, A. M. (1994). Qualitative data analysis: An expanded sourcebook. Thousand Oaks, CA: Sage Publications.

[7] Popper Karl (2002). Conjectures and Refutations, The Growth of Scientific Knowledge. London: Routledge Classics (First Published 1963).

[8]. Popper, Karl Raimond (1994). The Myth of the framework: in defense of science and rationality. Editor: Mark Amadeus Notturno.

[9] RoutledgeRainbow, Paul A. (Paul Andrew) (2014). Johannine Theology: The Gospel, the Epistles, and the Apocalypse. Downer Grove, IL: InterVarsity Press.
[10] Luuk van de Weghe and John A. Battle, Truth and Semantic Change in the Gospel of John, Bulletin for Biblical Research, Vol. 31, No. 2 (2021), pp. 211-227 (17 pages). Published By: Penn State University Press.

[11] What is Truth According to the Apostle John?

https://ministryofstudy.wordpress.com /2014/09/08/what-is-truth-accordingto-the-apostle-john/ [aceessed on 2oth July 2021].

[12] What is Truth a Description of the Nature of Truth in the Gospel of John, https://bellatorchristi.com /2019/09/30/what-is-truth-adescription-of-the-nature-of-truth-inthe-gospel-of-john/ [aceessed on 21st July 2021]. 